University of Pennsylvania Carey Law School

Penn Law: Legal Scholarship Repository

Faculty Scholarship at Penn Law

10-10-2005

\title{
The Corporate Form as a Solution to a Discursive Dilemma
}

Edward B. Rock

University of Pennsylvania Carey Law School

Follow this and additional works at: https://scholarship.law.upenn.edu/faculty_scholarship

Part of the Business Organizations Law Commons, and the Other Economics Commons

\section{Repository Citation}

Rock, Edward B., "The Corporate Form as a Solution to a Discursive Dilemma" (2005). Faculty Scholarship at Penn Law. 80.

https://scholarship.law.upenn.edu/faculty_scholarship/80

This Article is brought to you for free and open access by Penn Law: Legal Scholarship Repository. It has been accepted for inclusion in Faculty Scholarship at Penn Law by an authorized administrator of Penn Law: Legal Scholarship Repository. For more information, please contact PennlawIR@law.upenn.edu. 


\title{
The Corporate Form as a Solution to a Discursive Dilemma ${ }^{1}$
}

\author{
(Forthcoming: Journal of Institutional and Theoretical Economics)
}

\author{
Edward B. Rock ${ }^{2}$ \\ University of Pennsylvania Law School
}

\begin{abstract}
I examine the connection between the discursive dilemma and corporate law. The discursive dilemma (or doctrinal paradox) is a distinctive social choice problem that was first identified by Kornhauser and Sager and later used as the basis for a theory of organizational personality by Pettit. I examine the ways in which the corporate form prevents the emergence of the discursive dilemma in the firm context and the extent to which the presence of the discursive dilemma can provide the foundation for a theory of corporate personality.
\end{abstract}

(J.Econ.Lit. classification: D23, D70, D71, K20, K22, L20, L21, L22)

One of the old legal chestnuts is whether "the personality of the corporation aggregate is in no sense and no sort artificial or fictitious, but is every whit as real and natural as is the personality of a man."” The "realist" view, most closely associated with

\footnotetext{
${ }^{1}$ Thanks for comments from: Zohar Goshen, Oliver Hart, Ted Janger, Michael Klausner, Lewis Kornhauser, Michael Moore, Phillip Pettit, Larry Ribstein, Erich Schanze, Ken Scott, Lynn Stout, Eric Talley, and participants in the UCLA/Sloan Conference on "The Means and Ends of Corporations," the New Institutional Economics conference on "Interacting with a Corporate Actor" at Kloster Irsee, and workshops at University of Illinois and the University of Pennsylvania. This article emerged out of two years of co-teaching a seminar on "Philosophical Issues in Corporate Law" with Leo Katz and owes an enormous debt to the numerous conversations we had in preparing and teaching together. A significant debt is also owed to the intrepid students who signed up for, and remained in, such an unusual not to say odd seminar. This research was supported by the University of Pennsylvania Institute for Law and Economics and the Saul A. Fox Research Endowment.

${ }^{2}$ Saul A. Fox Distinguished Professor of Business Law, University of Pennsylvania Law School.

${ }^{3}$ Maitland [1900].
} 
von Gierke and his followers, raises the question "whether the organized group of men has not a will of its own - a real, not a fictitious, will of its own - which is really distinct from the several will of its members.” ${ }^{, 4}$ It is this set of questions that I wish to address here.

\section{Introduction: A Simplified Corporate Decision}

Suppose that a commodity chemical company is engaged in a strategic planning exercise. $\mathrm{X}$, an extremely attractive specialty chemical operation, is on the market. The decision can be broken down as follows: should the firm enter the specialty chemical business or some other business? If it decides on specialty chemicals, should it do so by acquisition or by internal expansion? If it decides to expand by acquisition, should it acquire $\mathrm{X}$ ?

Consider the following stylized views. A takes an aggressive stance: in favor of both expansion into specialty chemicals and doing so by acquisition, and thus is in favor of acquiring X. B, by contrast, thinks that the firm should stick to its knitting (commodity chemicals) but if it is to expand into specialty chemicals, better to do so by acquiring a firm that already knows the business than to try to learn a new business. As a result, B opposes the acquisition of X. C, by contrast, agrees that the firm should expand into specialty chemicals, but is chastened by the number of failed mergers, and thus prefers expansion by internal growth rather than by acquisition. Because of C's skepticism about acquisitions, C opposes the acquisition of X.

\footnotetext{
${ }^{4}$ Id.
} 
Each of these positions is an entirely rational and consistent position. And yet, when the three positions are put together, there are some peculiar results. Let us construct the following table:

\section{Specialty Chemicals?}

$\begin{array}{llll}\text { A } & \text { Yes } & \text { Yes } & \text { Yes } \\ \text { B } & \text { No } & \text { Yes } & \text { No } \\ \text { C } & \text { Yes } & \text { No } & \text { No }\end{array}$

Here, two out of three are in favor of expanding into specialty chemicals, two out of three believe that, if the firm is to expand, it should do so by acquisition, yet two out of three would oppose acquiring $\mathrm{X}$, the available and attractive specialty chemical maker. Whether the firm decides to acquire X depends on whether it adopts a "premised-based” or a “conclusion-based” decision procedure.

This “dilemma” or "paradox,” first discussed by Lewis Kornhauser and Larry Sager $^{5}$ and subsequently taken up by Phillip Pettit, has deep implications for how we understand corporate law and corporate personality. In this Article, I do a number of things. First, I explore the connection between the discursive dilemma and the corporate context. Second, I examine the features of the corporate form can solve or prevent the emergence of a discursive dilemma through "collectivizing reason”. Finally, I briefly examine the implications of this analysis for other corporate law controversies.

\section{Some Background.}

\footnotetext{
${ }^{5}$ As discussed below, this is not, on its face, the same as the famous Condorcet/Arrow voting paradoxes, although the two bear a resemblance.
} 


\section{a. Kornhauser \& Sager's "Doctrinal Paradox"}

Lewis Kornhauser and Larry Sager, ${ }^{6}$ examining appellate decision making, discovered this very interesting dilemma. Suppose that the prevailing contract doctrine provides that, for liability, the plaintiff must establish the existence of a contract and also that the defendant behaved in a way which, if a contract exists, breaches the contract. Suppose that the three judges on the panel, after listening to arguments, and after discussion, come to the following set of conclusions:

\section{Judge}

$\begin{array}{ll}\text { A } & \text { Y } \\ \text { B } & \text { N } \\ \text { C } & \text { Y }\end{array}$

Breach?

$\begin{array}{ll}\mathrm{N} & \mathrm{N} \\ \mathrm{Y} & \mathrm{N} \\ \mathrm{Y} & \mathrm{Y}\end{array}$

As before, there is a conflict between the majority view on the premises and the majority view of the outcome: two out of three of the judges believe that there was a contract; two out of three believe that there was a breach; yet two out of three conclude that there was no liability. If the panel decides the case on a "premised based" approach (voting separately on whether there was a contract and whether there was a breach, and allowing prevailing contract doctrine, acting on these premises, to provide the conclusion), plaintiff prevails. If, on the other hand, the panel decides the case on a “conclusion based" approach, defendant prevails because two out of the three judges does not think that there was liability.

This same dilemma can easily arise in a variety of different contexts, and generalizes beyond the three judge appellate panel. Kornhauser and Sager use it to

\footnotetext{
${ }^{6}$ Kornhauser and Sager [1986], [1992].
} 
analyze some close and controversial Supreme Court cases, and, in so doing, explore its jurisprudential implications.

\section{b. Pettit's Extension of Kornhauser \& Sager's Analysis}

In an interesting series of articles, Philip Pettit exploits the dilemma (which he refers to as the "discursive dilemma”) to construct a theory of group identity and group rationality by taking what is usually viewed to be a decision making pathology to be the foundation for such a theory. ${ }^{7}$ This Article is an attempt to trace out the implications of Pettit's analysis for corporate law.

There are several pieces of Pettit's analysis that will be important for our purposes. First, Pettit observes that this “discursive dilemma” occurs outside of the appellate context, and can arise in any context of group decision making. It has particular bite, however, where groups are organized to achieve particular goals. In such circumstances, the disjunction between the results of premised-based decision making and conclusion-based decision making are particularly dramatic, especially when decisions are made over time and groups must maintain coherence in order to maintain credibility.

Consider a favorite example of Pettit's. A poll of a political party’s members reveals the following set of views (taking $\mathrm{A}, \mathrm{B}$ and $\mathrm{C}$ as the three camps within the party):

\section{Increases taxes? Increase defense spending? Increase other spending?}

A No Yes $\quad$ No (reduce)

${ }^{7}$ See, e.g., Pettit [2003a], [2003b]. 


$\begin{array}{llll}\text { B } & \text { No } & \text { No (reduce) } & \text { Yes } \\ \text { C } & \text { Yes } & \text { Yes } & \text { Yes }\end{array}$

Here, each camp’s views are entirely consistent over time. Yet, if the questions arise sequentially rather than simultaneously, and are resolved by majority vote, the party "will face the hard choice between being responsive to the views of its individual members and ensuring the collective rationality of the views that it endorses.”8 ${ }^{\text {Pettit }}$ argues that the pressures to retain credibility before the electorate will push the party apply the discipline of reason at the collective level, rather than merely at the individual level. ${ }^{9}$

Pettit's key point is that groups that seek to accomplish goals face strong pressures to “collectivize reason” in order to achieve those goals. Groups that collectivize reason are, in Pettit’s terms, “social integrates.” These social integrates display an interesting set of properties. First, a gap opens between the views advanced by the social integrate and the views of its members. In imposing "the discipline of reason at the collective level, [the social integrate runs] the risk of collectively endorsing a conclusion that a majority of them - perhaps even all of them - individually reject.”"10 Second, the social integrate will display the kinds of coherence and consistency that characterize an “intentional subject” that is distinct from its members. Indeed, on Pettit's analysis, social integrates will display exactly those properties that philosophers take to

\footnotetext{
${ }^{8}$ Pettit [2003a].

${ }^{9}$ Pettit [2003a] at 178.

${ }^{10}$ Id. at 175.
} 
be the requirements of rationality and personhood, winning them the characterization as “organizational persons.”11

Part of what is so interesting and persuasive about this analysis is that the gap (between the wishes, judgments, desires, intentions, actions, personality or whatever of the members and those of the social integrate) does not derive from any mysterious sort of special stuff. Indeed, social integrates clearly comply with any reasonable requirement of supervenience: the positions of the social integrate are dependent on the positions of the members; and the social integrate does not exist without its members. ${ }^{12}$ Yet the positions of the social integrate can differ substantially from those of a majority of the members.

\section{Discursive Dilemmas in the Firm}

Are discursive dilemmas pervasive features of firms or just an occasional pathology? It is hard to know. My stylized opening example suggests that it could arise but not that it does arise with any regularity. Moreover, if I am correct that the corporate form, either by design or serendipity, works to prevent the emergence of discursive dilemmas, then one would not expect to find many actual examples.

Whatever the actual incidence, in principle the discursive dilemma seems worth worrying about both because it can arise and, more importantly, because that possibility may help us better understand existing institutional structures. Note a feature of the opening situation. It may seem that the discursive dilemma only arises with respect to

\footnotetext{
${ }^{11}$ Pettit [2001] at 241, 243 (consistency, closure and completeness as the requirements of rationality). See, also, Pettit [2003b].

${ }^{12}$ Pettit [2003a] at 184.
} 
decisions over time, and can be avoided by stubbornly insisting on a conclusion-based decision procedure for any given decision. But it is misleading to think that the firm's freedom to choose between a premised-based and conclusion-based decision procedure will depend on how sub-decisions present themselves. While the particular decision at issue - should the firm acquire $\mathrm{X}$ - can be understood as arising synchronically and thus as preserving the firm's ability to choose between a premised based and conclusion based decision procedure, that opportunity is fleeting.

Suppose that the questions arise - as is often the case in any real context sequentially. The first issue presented is whether the firm should expand into specialty chemicals. Here, the vote is $2-1$ in favor, and, operating with a conclusion-based decision rule, the firm approves the plan. Six months later, the question is presented whether to expand by acquisition or by internal expansion. Again, expanding by acquisition is approved by $2-1$ in favor. Then, six months later, the opportunity to acquire $\mathrm{X}$ is presented to the firm. If the proposal to acquire $\mathrm{X}$ is presented under a pure conclusion-based decision rule, it will be voted down $2-1$. Yet an affirmative response follows naturally from the two earlier decisions. To vote down the acquisition is, in exactly the way identified by Pettit, for the firm to court incoherence. ${ }^{13}$

Does it matter that a firm is incoherent? Well, clearly it can. Firms function in a variety of contexts in which they are treated as units: firms enter into contracts with suppliers, customers, employees, and creditors; firms acquire and dispose of property;

\footnotetext{
${ }^{13}$ As Pettit [2003a] points out at 173: "Sooner or later such a group is bound to face an issue such that how it should judge on that issue is determined by the judgments it previously endorsed on other issues. And in such an event the group will face the old choice between adopting a conclusion centered procedure and adopting a premised centered one.”
} 
firms launch ventures, adopt strategies, and so forth. In each of these and other contexts, it matters to the firm's credibility if it can be expected to behave coherently.

My claim here is that the market pressures can push an enterprise in one of two directions: either a group embraces its "aggregateness" (here think of a small law firm in which each lawyer has separate clients or a real estate agency in which the agents work on a straight commission); or, when there are advantages to, or a necessity for, unified action, success will require coherence. In this second context, when coherence matters, the firm cannot choose the collective incoherence generated by stubbornly sticking to a conclusion-based decision procedure.

Pettit identifies two main choices of decision procedures for avoiding the discursive dilemma. One alternative is to collectivize modus ponens at the level of premises: a majority vote on a set of premises will be taken to endorse a conclusion that flows from them. Or, equivalently, a group can practice modus tollens: it can ignore the majority vote on one of the premises while accepting the majority vote on the other premises and the conclusion they support. ${ }^{14}$

In choosing among these strategies, the group is confronted with a trade off between "maximize[ing] responsiveness to individual views, running the risk of collectively endorsing inconsistent sets of propositions. Or they may impose the discipline of reason at the collective level, running the risk of collectively endorsing a conclusion that a majority of them - perhaps even all of them - individually reject.”15

\footnotetext{
${ }^{14}$ Pettit [2003a] at 174.

${ }^{15}$ Id.
} 
Importantly, the corporate context illustrates a different set of options for handling these decision making problems, namely, the adoption of institutional solutions. It is to this set of solutions that I now turn.

\section{Corporate Law and the Discursive Dilemma}

Why is it that for-profit firms are typically owned by the shareholders and not by the employees or some mix? Hansmann [1996] argued that a key determinant is the heterogeneity of the interests of the owners: where heterogeneity is high, the cost of decisions increases. ${ }^{16}$ Shareholders, qua shareholders, have largely (perhaps perfectly) homogeneous interests: they want nothing more than to maximize the value of the firm. As such, shareholder-owned firms, Hansmann argues, will have the lowest decision costs and, in competitive markets, can be expected to survive.

But the discursive dilemma suggests that heterogeneity of interests is only the starting point of an analysis. Even when the participants have a common goal (in the case of the firm, maximizing firm value), the discursive dilemma is likely to arise because of the nature of collective decision making over time. The existence of a homogenous interests generated by a common goal merely poses the problem; it does not solve it.

\section{a. The Discursive Dilemma and Cycling Problems}

The discursive dilemma bears a resemblance to the Condorcet/Arrow-type cycling paradoxes that have generated a huge literature. In substance, however, it seems to be quite different. Recall the standard set up for a cycling problem: A prefers Chocolate over Vanilla over Strawberry; B prefers Vanilla over Strawberry over Chocolate; C

\footnotetext{
${ }^{16}$ Hansmann [1996], Ch. 6.
} 
prefers Strawberry over Chocolate over Vanilla. In these circumstances, each question posed will have a determinate answer, but, in aggregate they are inconsistent: thus, in C v. V, C wins; in V v. S, V wins; and in S v. C, S wins, with the policy chosen depending on who sets the agenda. Here, by contrast, you have a related problem with a very different cause: namely, it derives from the choice of decision rule (premise based versus conclusion based) rather than the agenda. Moreover, the outcome is really quite different: in the cycling context, even after the fact, two out of three will support the choice as presented; in the doctrinal paradox, on the other hand, if a conclusion based decision rule is chosen, the result will be opposed by two out of three. It is this latter feature - and the gap that a conclusion based decision rule opens between the decisions of the firm and the decisions of the participants - that makes the discursive dilemma an interesting starting point for a theory of corporate personality. ${ }^{17}$

\section{b. Corporate Law Solutions}

How is the discursive dilemma resolved or at least controlled in the corporate context? This is an interesting question from two perspectives: first, what it tells us about corporate law; second, what it tells us about how social integrates are created and preserved.

As Jeff Gordon pointed out with respect to cycling problems, corporate law’s pacification of shareholders prevents cycling. It also prevents the emergence of the discursive dilemma. In corporate law, one observes several strategies: limitations on participation; creation of intermediate institutions; and pre-commitment strategies.

\footnotetext{
${ }^{17}$ Jeff Gordon has explored the connection between corporate law's pacification of shareholders and cycling problems in Gordon [1991]. Whether the discursive dilemma is isomorphic with Condorcet cycling is an intriguing question that is beyond my ability to answer.
} 
The first set of strategies preempts the emergence of the discursive dilemma by limiting occasions on which members can express their preferences. Under Delaware corporate law, absent special provisions, shareholders only get to vote on a very narrow range of issues. Shareholders and shareholders alone elect directors. Beyond that, shareholders' votes are largely limited to vetoes over board decisions: shareholders must approve a merger or sale of all or substantially all the assets proposed by the board; shareholders must approve modification to the certificate of incorporation (the corporation's constitutional document) proposed by the board; and, in some cases, must approve compensation arrangements. Aside from this narrow set of instances, there are a host of high stakes situations in which shareholder do not vote. Most importantly, the board is empowered to make major corporate investment and borrowing decisions without consulting with shareholders. ${ }^{18}$

The strategic planning process described above, then, would almost certainly not involve the shareholders. There are no circumstances in which shareholders could initiate and force such a move, and relatively few in which the board would be forced to allow shareholders to veto such a decision. So long as the specialty chemical operations are small relative to the size of the company, it is for the board alone to decide whether to expand into specialty chemicals, whether to expand by acquiring a small existing chemical company or by internal expansion, whether to do so by using retained earnings or debt, whether subsequently to acquire a second small specialty chemical company to further expand, and whether to sell the whole operation once the strategy has been completed. Even if the transaction is large relative to the size of the company, so long as

${ }^{18}$ Kraakman, et al, [2004] at Ch. 6. 
it can be financed with retained earnings or debt, shareholders have no say. Under Delaware law, shareholders have a veto right only if the transaction is structured as a straight merger (largely avoidable, if the board wishes) or if the number of shares issued to acquire $\mathrm{X}$ requires an amendment of the certificate of incorporation. ${ }^{19}$

The range of decision rights that shareholders have and do not have cannot be understood on a simple delegation theory. In particular, one cannot argue that the delegation makes sense either because shareholders rationally expect the board to have greater expertise over these sorts of decisions, or because the amounts at issue are too trivial to worry about. Shareholder decisional rights do not track the importance of the interests at stake. Shareholders get to vote on minor things like the change in the corporate name but not on major issues like taking on a vast amount of debt and then paying it out as a one-time dividend to shareholders, which can turn a debt-free firm into a highly leveraged one.

The delegation is also not explicable straightforwardly in terms of expertise. Return to the opening hypothetical: the decision either to acquire $\mathrm{X}$ or not is, at core, an investment decision that is not, in kind, all that different from the kind of decisions that investors make every day. While the board will have better information on firm specific synergies, investors may have a less distorted view of the overall investments available, and may well have better incentives (e.g., uninfluenced by empire building) to make the right decision.

\footnotetext{
${ }^{19}$ Under stock exchange rules, shareholders have a slightly larger veto role, but that is tangential to the present discussion.
} 
On the other hand, limiting participants' voting rights has the effect of preventing the emergence of the discursive dilemma. It is a way of formally adhering to a principle of majority rule, while avoiding the debilitating effects of the discursive dilemma.

There is another interesting feature of the occasions of shareholder vote. Shareholders, as mentioned earlier, get to vote on mergers. This means that any party seeking to merge with a firm knows that the board cannot, by its own action, commit to a merger. In terms of the preceding discussion, the publicity of the shareholder vote requirement allows for a separation between "firm decisions" and "shareholder decisions.” Whatever collective incoherence emerges from successive majority shareholder votes on major decisions can, to a degree, be cabined and not infect the coherence of the firm's decisions.

A second set of solutions is institutional. Corporation law creates several institutions that are well suited to contexts in which the discursive dilemma can arise. The most obvious of these is the board of directors. By creating a board of directors, and granting it the power to manage the business of the corporation, corporate law creates an intermediate organ whose task is to ensure coherence of corporate choices over time.

But note an interesting feature of this solution. The board of directors itself, as the earlier CEO example shows, can fall prey to the discursive dilemma. What prevents that from happening? What drives the board towards adopting a premise-centered decision process with a commitment over time to collectivized reason? Several features of the institutional context work together. First, the board must face election. When it has performed incoherently, it can become a target of shareholder opposition or of a potential acquirer who, through a tender offer, a proxy contest, or a combination of the two, will 
seek to replace the board with a different team. Second, and related, there are market checks on the board: the stock price of the publicly held company is a form of ongoing referendum on management performance that can be expected, at least at times, to punish incoherence that results from an inadequate solution of the discursive dilemma. Third, to the extent that directors with relatively homogeneous views (or at least personalities) can be chosen - directors committed to premised centered decision making with commitment to the discipline of reason - the board level decision making will be less prey to the discursive dilemma than shareholder level decision making. Fourth, because the number of directors will be far smaller than the number of shareholders in the publicly held firm, the costs of achieving consensus, and of adjusting positions to achieve coherence over time, will be much less. Moreover, to the extent that there is a norm of meeting and discussion, it may (but need not) lead to a great degree of consistency over time. Finally, one standard defense of a CEO-centered model of board governance may be applicable, namely, that allowing the CEO to pick the directors will lead to greater coherence in corporate strategy. $^{20}$

A second institutional solution is the annual meeting of shareholders. One way of understanding the annual meeting is that it limits the opportunities for shareholder input to once a year. Similarly, the limited menu of topics that can be raised at the annual meeting likewise limits shareholder involvement and thus limits the opportunities for the discursive dilemma to arise.

The shareholders' ability to pre-commit to particular arrangements similarly facilitates the solution of the discursive dilemma and the creation of a social integrate.

\footnotetext{
${ }^{20}$ For a related analysis, see Bainbridge [2002] at Ch. 5 (Director Primacy).
} 
Under Delaware corporate law, provisions in the corporate charter are entrenched: they can only be changed by a recommendation of the board of directors combined with approval of a majority of outstanding shares. ${ }^{21}$ Moreover, Delaware law permits shareholders to place any provision relating to the management of the company into the charter, so long as it does not violate any law. ${ }^{22}$ These constitutional commitments take a variety of forms. The most prominent is the "classified" or "staggered" board. On such boards, directors typically have three year terms with only one-third of the directors facing election each year. The effect of the effective staggered board is that it takes two annual meetings for a competing team to gain power because it takes two elections for the competing team to gain a majority at the board level. Firms that opt for staggered boards are thus opting to entrench the directors.

But other provisions, granting more or less opportunity for shareholder participation, can also be included in the charter and sometimes are. In some firms, the charter requires a shareholder vote on poison pills. In other firms, the charter provides for some shares to have multiple votes, with other shares having fewer or no votes. Together, these devices permit shareholders to make commitments that will endure, even in the face of a majority of shareholders with contrary views. In other words, they allow shareholders ex ante to establish and entrench mechanisms for "collectivizing reason" against the foreseeable possibility that, ex post, at least in some cases, there will be a conflict between the demands of reason and the views of a majority of the shareholders.

\footnotetext{
${ }^{21}$ Delaware General Corporation Law (GCL) §242. For a more extensive discussion of "corporate constitutionalism”, see Kahan and Rock [2003].

${ }^{22}$ Del. GCL §102(b)(1).
} 
A fourth set of features relates to the preservation of the social integrate that emerges from the premise centered solution to the discursive dilemma. A key difference between the classic general partnership and the corporation is that in a partnership, every partner has the power to cause the dissolution of the partnership and the distribution of the assets, while in a corporation, shareholders are locked in: no shareholder alone can cause the dissolution of the firm. Rather, dissolution requires a recommendation by the board combined with a vote of a majority of the outstanding shares. ${ }^{23}$ This requirement further insulates the entity from the views of the shareholders, even a majority of the shareholders.

In summary, then, the corporate form is well suited to the creation and preservation of social integrates. The "pacification" of shareholders prevents many discursive dilemmas from arising, while the "lock-in" prevents disintegration when a gap opens between the view of the shareholders and the view of the corporation.

Indeed the radically different dissolution rules of partnerships and corporations suggests that menu of enterprise forms serves to allow groups to choose, to a significant degree, whether they wish to become social integrates or not. ${ }^{24}$ When, as in the case of a small law firm, the appropriate organizational structure is a social aggregate, with each partner in control of his own clients, the general partnership is the enterprise form that

\footnotetext{
${ }^{23}$ Del. GCL §275.

${ }^{24}$ Lucian Bebchuk argues that the cycling problems that Jeff Gordon focuses on can be avoided without significant infringement on shareholders sovereignty simply by giving management the ability to place counter-proposals on the same agenda (presumably to be voted on after shareholders' proposals). Bebchuk [2005]. Bebchuk's argument is that this ability will allow managers to maintain the status quo where cycling is present, and that, as a result, shareholders will only make proposals that trump any of the existing options. Whether or not Bebchuk's proposal solves cycling problems, it does not resolve the discursive dilemma for the reasons discussed above, namely, that it is not a matter of agenda control but arises from a gap between individual and collective rationality.
} 
best serves those purposes. By contrast, when it is important to the success of the firm to create a social integrate, the corporate form serves that goal.

\section{c. Would Transactions Among Shareholders Eliminate the Need for Pacification?}

Consider another objection: can side payments among shareholders solve the discursive dilemma without resort to delegation/pacification ${ }^{25}$ This is an interesting objection that reveals some interesting properties of the legal structure.

First, shareholders will typically be free to sell their shares or enter into binding coalitions. In this circumstance, if the A faction feels strongly that acquiring $\mathrm{X}$ is the right thing to do, it may well be able to acquire enough shares or votes from the B and or C factions to gain a control position (or contrariwise for B and C). If one faction buys out the others, that faction will then be able to implement its preferred strategy. Although there may be a bit of delay caused by legal detail, the majority shareholder will ultimately have its way. Put differently, the shareholder disenfranchisement or pacification discussed above only applies to when no faction has control and when no voting coalitions can be formed, i.e., only to dispersed ownership structures, not to concentrated ownership structures.

There may, however, be a significant number of situations in which the factions will not be able to work out their disagreements internally. This may be because of collective action problems or because no faction is sufficiently confident in its view of optimal corporate strategy or because no faction has enough money for one reason or another. These are precisely the cases in which discursive dilemmas threaten firm

\footnotetext{
${ }^{25}$ Lynn Stout and Oliver Hart each brought this point to my attention.
} 
consistency and also the situations in which the legal structure eliminates the threat by allocating the decision to the board.

In other words, the legal structure actually seems to play a channeling role: when the discursive dilemma can be solved by side payments, the structure permits it; when it cannot, the solution is to pacify shareholders and kick the decision to the board. As I argue above, this cannot be explained on straightforward delegation grounds: either on the grounds of expertise (because these include pure investment decisions); or on grounds of trivial stakes (because these can be bet the company decisions), but can be explained as a solution to the discursive dilemma.

\section{Implications: Are Corporations “Organizational Persons”?}

\section{a. Social Integrates and the "Theory of the Firm"}

There is an interesting link between this analysis of "social integrates" and the “theory of the firm” generally associated with Oliver Williamson and Oliver Hart (working alone and with Sandy Grossman and John Moore). In particular, it holds the promise to provide a "theory of the corporation" as distinct from a "theory of the general partnership” and of other enterprise forms. Let me sketch out this connection.

For Pettit, the difference between a "social integrate”, like the Democratic party, and a "social aggregate", like the American electorate (or red heads, or Philadelphia 76ers fans), is the extent to which reason is collectivized. As he points out in connection with the aggregation of views on cutting taxes, increasing defense spending, increasing other spending, and holding the deficit constant, it is perfectly possible for individual voters to hold entirely coherent and rational views, and for the aggregate of those views 
to be inconsistent. In that case, it is a stretch to say that "the American Electorate” has incoherent preferences. By contrast, a party that advocated the same set of views (cut taxes, increase defense spending, increase social spending, hold the deficit constant) would make itself ridiculous.

From one perspective, the collectivization of reason is a cost that the group must bear. After all, it results in a divergence between the interests, desires, views or whatever or the members and the group. While that is true, a better way to think about it is that the choice to carry out some activities through a social integrate - to seek to achieve some aims - is in fact the choice to collectivize reason as opposed to distributing reason through more atomistic interactions.

Here we link up with the theory of the firm. A key insight of the theory of the firm literature is that the firm/market boundary - the choice between locating activities within a firm versus buying inputs through the market - is a choice between two different modes of governance. Where inputs are available in competitive markets, there is no reason to give up the robust protection of markets in order to bring activities into the firm. But when markets cannot be used - typically because of the nature of the assets at issue - activities are brought within the firm to take advantage of the different mode of governance that prevails.

The same sort of argument seems to apply more generally. Why or when are social integrates formed? Because of the cost of collectivizing reason in terms of its divergence from the views of the participants, the answer must be roughly that social integrates are formed when, despite the costs, there is a net benefit to achieving the goals collectively. Just as the theory of the firm literature teaches that it is the distinctive 
governance structure available within the firm that explains the "make or buy" decision, so too, it is the distinctive rational unity of the social integrate - complete with the divergence of institutional views from the views of a majority of the members - that provides the explanation for why some activities are carried out within social integrates and others outside.

The theory of the firm demonstrates, in the firm context, that this is not a mere tautology. Much of the work over the last two decades has focused on understanding precisely what differences explain the decision to bring activities within the firm and to make them subject to the intra-firm mode of governance. Is it the nature of "human capital" and the difficulties of writing enforceable contracts governing the cost of training? Is it the need to control access to physical assets as a mechanism for solving the contracting problem over human capital? Is it the fact that some assets are worth substantially more to the participants in the enterprise than to third parties (i.e., are "transaction specific assets"), and the difficulties of writing enforceable contracts over such assets?

The discursive dilemma provides a somewhat different justification for firms, and, in particular, corporations. The market and the firm are, of course, both mechanisms of aggregation. They differ precisely in their ability to respond to the discursive dilemma. The market's strength and weakness is that it simply aggregates preferences. The "stock market” is the paradigmatic example of a social aggregate. Any statements made about the stock market (e.g., "the market was optimistic today" or "the market was spooked by Greenspan's speech”) are entirely summary and nothing but a short hand (equivalent to "most or many buyers and sellers were optimistic" or "many traders were spooked by 
Greenspan’s speech"). If, over time, the market behaves "irrationally" that is understood as a short hand description of the actions of participants or sometimes simply a funny result of aggregation of preferences.

By contrast, the corporation (much more than the partnership) has the institutional capacity to constrain the discursive dilemma. That suggests that where particular sorts of complex activities engaged in by groups of people require coherent decision making over time, that those activities will be organized as firms. This explanation for the existence of firms - one that is based on minimizing a particular sort of decision cost, namely, the discursive dilemma - is related to Williamson's focus on the firm as a hierarchical governance mechanism and Hart's focus on property rights, but, I think, focuses on a different aspect of the problem of organizing activities.

Here, the critical difference between the corporation and the general partnership is the difference in the rules governing dissolution. ${ }^{26}$ As discussed above, the corporation can only be dissolved by agreement between the board and a majority of the shareholders, absent shareholder unanimity. By contrast, every general partner has the power to either dissolve the partnership (under the Uniform Partnership Act) or to dissociate from the partnership, leading to a buy out procedure (under the Revised Uniform Partnership Act). It is this difference which permits the corporation to adopt positions that depart from the positions of a majority of the shareholders, and thus act as a social integrate rather than aggregate.

\section{b. Other implications}

\footnotetext{
${ }^{26}$ For a more extensive discussion of this point, see Rock and Wachter [1999].
} 
The upshot of the previous analysis is that corporations are a paradigmatic example of what Pettit wants to call "groups with a mind of their own." In situations in which the “discursive dilemma” arises, it is entirely accurate to say that the corporate decision, preference or judgment is not simply aggregative of the decision, preferences or judgments of the shareholders. Indeed, as we've seen, it may well be the case that the unambiguous judgment of a majority of the shareholders, if asked to vote, is opposed to that of the corporation. This is why the discursive dilemma is, in some respects, more interesting than the standard cycling problems. In a cycling problem, the problem is that too many views command a majority of support, with the winner depending entirely on setting the agenda. In the doctrinal paradox, the pathology is otherwise: under any construction of shareholders' current preferences, judgments or opinions, 2 of 3 reject acquiring X. Many features of corporate law can be understood as facilitating the creation of such perhaps superficially odd social integrates, and preserving those that emerge.

This raises the question - beyond the scope of the paper but the subject of on-going research - of whether the corporate solution to the discursive dilemma can form the foundation of a broader but still thin and philosophically parsimonious concept of corporate personality, and, if it can, what follows. I can only sketch the outlines of the discussion here.

If one takes the view that a person is an intentional subject that manifests a commitment to rational unity over time (i.e., can be called upon to justify inconsistent behavior), then, on this thin notion of personhood, a corporation can (but need not necessarily) count as a person. But the question is less whether corporations can count as 
persons on some thin concept of personhood, than why it should matter whether corporations are persons in this sense. After all, if an investor is faced with the choice of saving her child or her corporation, the choice should be an easy one!

There are several ways in which it might matter. First, even a thin concept of person would be sufficient to anchor the common social practice of thinking of, and speaking of, corporations as if they were persons. We applaud Apple for the iPod and criticize Exxon for oil spills. Second, even a thin concept of corporate personhood raises interesting questions for criminal law: what sorts of persons are the appropriate targets of criminal sanctions? Third, once we think of corporations as persons even in this thin sense, we can give some concept to the notion of corporate weakness of will, which is a version of managers' perennial complaint about shareholders' short sighted pursuit of short term gain at the cost to long term profitability.

But the main payoff is more abstract. The threat of the discursive dilemma, and corporate law's response to it, provides the basis for an understanding of the corporation which is not reducible to summary aggregation of the views of the shareholders, and an understanding of the corporation that is more than simply a nexus of contracting. 


\section{References:}

Bainbridge, S. [2002], Corporation Law and Economics, Foundation Press: New York, NY.

BeBChuK, L. [2005], “The Case for Increasing Shareholder Power,” Harvard Law Review, 118: 833-917.

GoRDON, J. [1991], "Shareholder Initiative: A Social Choice and Game Theoretic Approach to Corporate Law,” University of Cincinnati Law Review, 60: 347-385.

Hansmann, H. [1996], The Ownership of Enterprise, Harvard University Press, Cambridge, MA.

KahAn, M., AND E. Rock [2003], "Corporate Constitutionalism: Antitakeover Charter Provisions as Precommitment,” University of Pennsylvania Law Review, 152: 473-522.

Kornhauser, L. AND L. SAger [1993], "The One and the Many: Adjudication in Collegial Courts," California Law Review, 81:1-59.

KoRnHAUSER, L. AND L. SAGER [1986], “Unpacking the Court,” Yale Law Journal, 96:82-117.

Kraakman, R., P. Davies, H. Hansmann, G. Hertig, K. Hopt and E. Rock [2004], The Anatomy of Corporate Law: A Comparative and Functional Approach, Oxford University Press: New York, NY.

MAITLAND, F. [1900], “The Corporation Sole,”Law Quarterly Review 16: 335-54.

PetTit, P. [2003a], “Groups with Minds of their Own,” pp. 167-93 in Frederick Schmitt, ed., Socializing Metaphysics, Rowan and Littlefield: Lanham, Md.

PeTTIT, P. [2003b], “Akrasia, Collective and Individual,” pp. 68-96 in Sarah Stroud and Christine Tappolet, eds, Weakness of Will and Practical Irrationality, Oxford University Press: Oxford.

PetTiT, P. [2001], “Collective Intentions,” pp. 241-254 in N.Naffine, R.Owens and J.Willlams (eds.), Intention in Law and Philosophy, Ashgate: Dartmouth.

Rock, E., and M. Wachter [1999], "Waiting for the Omelet to Set: Match-Specific Assets and Minority Oppression in the Close Corporation,” Journal of Corporation Law, 24: 913-948. 